\title{
AMFI's Reality School: A Circular Economy Agenda for Fashion Education
}

\section{Nicholas Hall and Fiona Velez-Colby}

\begin{abstract}
The circular economy (CE) agenda is gaining traction within the fashion industry and increasingly within fashion education (Ghisellini, Cialani and Ulgiati 2016:11). It provides a connective, interdisciplinary framework that offers a roadmap for transition towards a sustainable economy. As business eco-systems re-align to meet new standards of ethical and sustainable practice for the fashion industry, a new agenda for fashion education emerges: one of circularity (Junyent and de Ciurana 2008:764).
\end{abstract}

This article evaluates Amsterdam Fashion Institute's (AMFI) Reality School concept; examining how circular economy education is being embedded within it and the levels of integration achieved. It argues that a CE approach to curriculum design can motivate deep learning, through experimental practice, deep-dive research and systems thinking. It provides a structural framework of a $\mathrm{CE}$ agenda to fashion education curriculum, establishing a novel approach that could be applied to other specialist fashion education institutions.

\section{Introduction}

The contemporary challenge for the fashion industry is to transition towards circular economy (CE) practice. The adoption of CE requires two key elements:

- sustainable re-industrialization: a re-engineering of how we design and make things

- a new focus on the knowledge, skills and competencies required to create sustainable production and consumption.

A new agenda for fashion education emerges; the skills and knowledge needed for enabling CE must be embedded within fashion education. This paper provides an evaluative case study of how the Amsterdam Fashion Institute (AMFI) is transitioning towards embedded CE education by evaluating its Reality School approach to applying CE as a core pedagogic approach in its curriculum design.

The article argues that applying the interconnected and multi-disciplinary approaches of CE to curriculum design can motivate pedagogic innovation and stimulate deep learning. It proposes a model to map student learning progression through CE curriculum design and identifies key structural frameworks required for institutional transition toward CE fashion education.

\section{Background}

The Fashion Industry has long perpetuated the take, make, use, dispose paradigm of a linear economy (Ellen Macarthur Foundation 2016:19). The fashion industry's rapid and unprecedented globalization has been underpinned by the quantity and variety of garments it is able to design, and the speed at which it can manufacture and distribute products. Fastfashion in particular has pursued a 'race to the bottom' cost ideology, using operational efficiency and economies of scale to offer high volume, low-cost goods that encourage overconsumption. It is a global production system that produces 80 billion garments a year, 75 per cent of which end up in landfill (Greenpeace 2016:5). The scale of demand and materials 
throughput mean it is a system rapidly reaching the limits of its resource. The fashion industry is responsible for 10 per cent of global carbon emissions, making it the second most polluting industry in the world (GCU The Fair Fashion Centre Website 2017). Two of its key production activities, tannery operations and dye industries, are in the top ten most toxic in the world (Blacksmith Institute Website 2012). Further environmental impacts include widescale water waste and pollution in textile-producing nations (Hasan and Miah 2014:9), degradation of agricultural capabilities that support cotton production (Better Cotton Initiative Website 2017), deforestation for cellulosic fibres that results in 70 million logged trees a year (Conca 2015) and the intensive energy requirements and greenhouse gas emissions involved in synthetic textile production (ECOTEXTILES Website 2011). In addition, there are ethical issues with the wide-spread adoption of exploitative models of cheap labour that use impoverished garment workers with few human rights as the engine of its productivity (Maher 2010:3). Though not immediately obvious to the cost-conscious fashion consumer, this is a system in crisis, one that has created a perfect storm of tipping points and limitations that clearly make the fashion industry unsustainable.

$\mathrm{CE}$ is a connective, interdisciplinary framework that offers a transitional roadmap toward a sustainable fashion industry. It provides a systems thinking approach that identifies the interrelatedness of problems and the interconnectedness of solutions encompassed in an achievable vision of a new economic paradigm. It proposes to realign production and consumption systems to imitate natural cycles of reuse and zero-waste (Ellen Macarthur Foundation 2016:22). Priority is placed on the continuous value of resources and materials throughout the life cycle of product, production and consumption, seeking to create a regenerative system where reuse, reduce and recycle are a basic currency with less emphasis on ownership and far more placed on returning borrowed resources into a closed loop production system. Reprocessing, remanufacturing and industrial ecology are normalized and products redesigned to meet a new standard of sustainability, embracing Cradle to Cradle design (McDonough and Braungart 2002:93). At the same time, reliance on virgin raw materials and their conversion into useable manufacturing commodities is reduced and ultimately phased out in favour of circular production and new forms of industrial symbiosis.

\section{Methodology}

This article presents an evaluative case study of AMFI's approaches to embedding CE curricular into its Reality School concept and examines teaching practices across a sample of undergraduate and postgraduate provision. A pedagogic literature review of sustainable education and its relationship with deep learning was undertaken to establish the research aims for the article. In order to measure the overall level of adoption of CE into the Reality School, and establish AMFI's institutional progress towards the comprehensive integration of a $\mathrm{CE}$ agenda evidence was gathered through:

- an analysis of the level of CE curricular embeddedness within selected programmes.

- conducting semi-structured interviews with curricular leaders

- observation of a key knowledge exchange event, Beyond Green, including discussions about the challenges of embedding CE into fashion education.

A total of 5 people were interviewed for the article. Respondent 1 is Head of Fashion and Design at AMFI and lead academic on MA Fashion Enterprise Creation, respondent 2 is sustainability lead at AMFI and programme lead for the Circle Textile Programme: Circle Economy (a CE Consultancy), respondent 3 is academic lead for the iNDiViDUALS [sic] programme, and respondents 4 and 5 are the academic leads for the 3D Hypercraft 
programme. A preparatory meeting was conducted with respondents 1 and 2 about the research aims of the article and took place via Skype approximately 3 weeks prior to the faceto-face semi-structured interviews. Subsequent to this meeting internal documents regarding the curriculum and teaching and learning structure of the courses was provided for analysis and review, after which 3 programmes and a knowledge exchange event were selected as case study examples of the different levels of CE embedded curriculum the within the school. Respondents 3, 4 and 5 were selected for semi-structured interviews because of their lead academic positions on those programmes and at the knowledge exchange event.

Face-to-face semi-structured interviews were conducted with respondents 1, 3, 4 and 5 during a two day visit to AMFI. Interviews were conducted on day one and the knowledge event was attended on day two. Respondent 2 was interviewed via Skype at a later date as they were unavailable during the visit. Interviews lasted approximately one hour. Respondents were asked questions based on four core themes which were developed through literature review and programme analysis:

1. Understanding how the Reality school and its programmes are set up to respond to and simulate the reality of the fashion industry.

2. Understanding how AMFI provides a motivational learning environment where students adopt a deep learning approach that develops their meta-learning skills and a strong and personal interest in sustainability.

3. Understanding how business and industry engagement have influenced curriculum design.

4. Discussion about the challenges AMFI is experiencing in embedding CE into its curricular and its responses to these challenges.

As a result of the pedagogic literature review, analysis of the course documentation, a visit to AMFI and the semi-structured interviews 3 models were developed:

- Figure 1. The Reality School Structure. An approximation of the reality school and how it functions.

- Figure 2. Model of Expected Student Learning Progression which demonstrates desired levels of learning and skills of students across three years of study.

- Figure 3. Levels of CE integration into curricular. A model of embeddedness identifying the different levels and challenges of embedding $\mathrm{CE}$ into a fashion education institution (an adapted model from Hurnery et al (2016))

The model adapted from Hurney et al (2016) (Figure 3.) was then used as an evaluative tool, forming case study analysis of the three programmes and the knowledge exchange event in order to assess the level of integration of CE achieved by each.

\section{AMFI Structure and Reality School Concept}

This article focuses on AMFI and its journey towards embedding a CE agenda as the foundation of its Reality School. AMFI is a well-established specialist fashion education institute with approximately 1100 undergraduate and post-graduate students (AMFI Website 2017). Students graduate with a BA in Fashion Textiles and Technology and are required to specialize in either Fashion and Design, Fashion and Management or Fashion and Branding, and can continue their studies at AMFI with a Masters in Fashion Enterprise Creation. Holding 36th position in the Global Fashion School Rankings 2017, it has an international reputation for sustainability, marketing and business (Business of Fashion Website 2017). 
For all undergraduate students, the programmes, or minors, they study in their first two years at AMFI ensure they have acquired the operational learning skills in preparation for deeplearning to occur when they enter the Reality School, their final year of study. The Reality School is underpinned by an autonomous and agile structure that allows programmes to accommodate and respond to industry challenges rapidly via a flexible curriculum facilitated by academics retaining control over programme specification and modifications using an internal approval meeting, without the need for authorization from additional University committees. This flexibility was demonstrated by AMFI's ability to react and move towards circularity two years ago when conversations with industry partners moved on from sustainability towards the institution-wide adoption of the $\mathrm{CE}$ agenda, a logical progression.

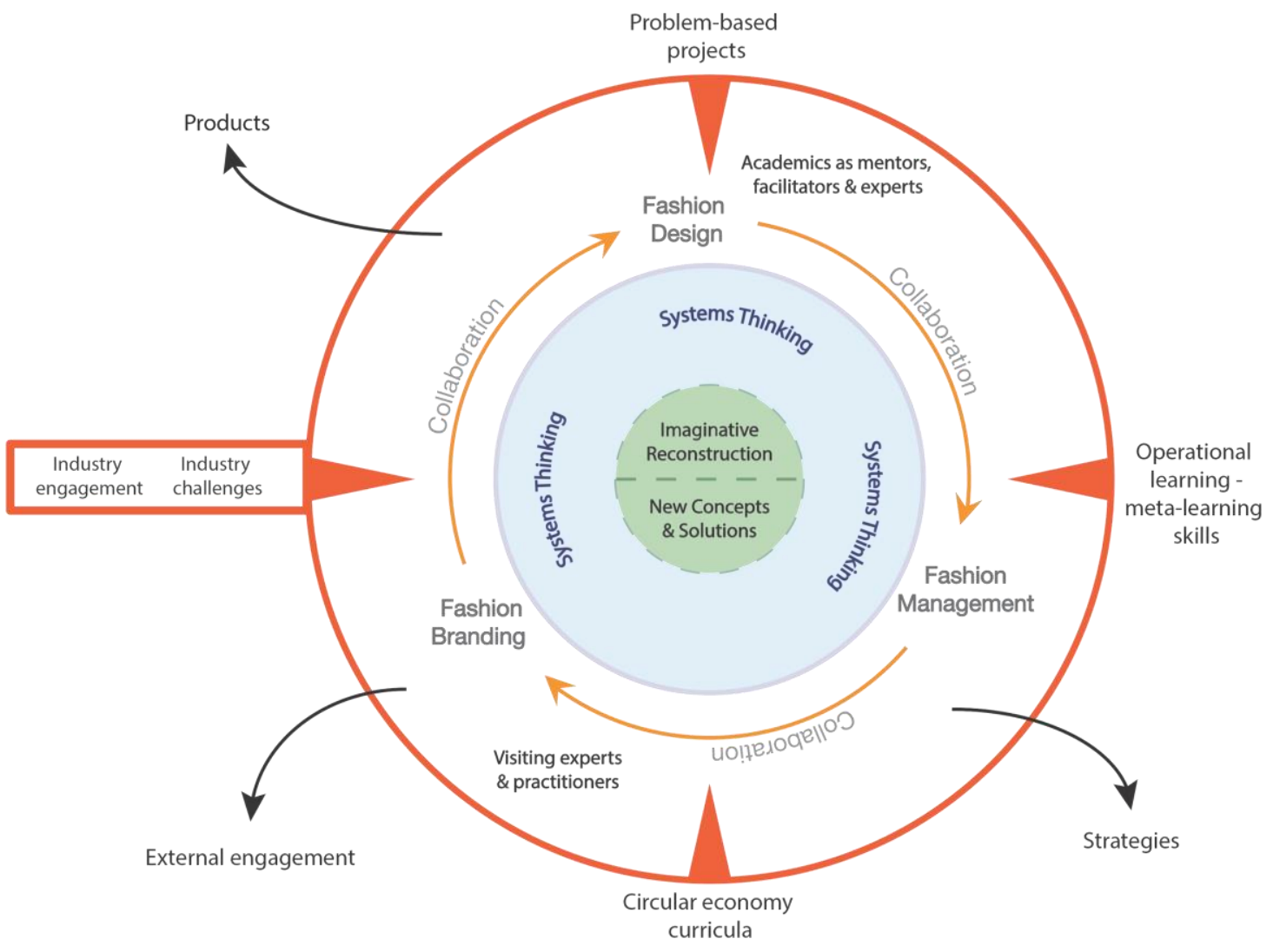

Figure 1. The Reality School Structure

The Reality School concept (Figure 1.) unifies the direction all of AMFI's third and fourth year students' work. It is a flexible structure that responds to the challenges of its industry partners who provide real projects linked to their existing and future commercial requirements. Within the programmes it offers, students explore their selected area of specialism through industry-connected or industry-led projects, but also engage in interdisciplinary practice through collaboration with students from different areas of specialism. The project outcomes result in professional products that are sold in the marketplace and strategies that are developed with and/or presented to industry. Students are able to achieve high-level outcomes because the structure of the Reality School is conducive to deep learning (Biggs and Tang 2007:27). Developing their meta-learning skills; selfregulation and self-motivation; independence as learners; creative confidence; reflection and criticality; research practice; professional skills; and technical expertise, in their first two years of study ensures that operational learning (Warburton 2003:47) is a core competency 
before students move into the holistic, independent learning adopted throughout the Reality School. Understanding, let alone solving, the issues inherent in the application of CE agenda requires the meshing together of complex and interrelated threads that cannot be easily grasped and, if students are to take on the challenges of CE, they must be provided with the meta-cognitive skills to do so.

Although AMFI's process of transformation is bolstered by an established focus on sustainability, the Reality School also demonstrates the need to form partnerships with knowledge providers who can strengthen the impetus for change and help provide the agency to carry out the paradigm shift required to move to a $\mathrm{CE}$ agenda. It is notable that in recent years AMFI's conscious shift towards teaching a CE agenda has been reinforced by a partnership with the Circle Textile Programme, part of Circle Economy; a social enterprise with a focus on knowledge exchange across a broad range of industries and government sectors. This partnership, AMFI's own initiatives such as Beyond Green, and close working proximity to Fashion for Good (an Amsterdam based global social enterprise) all act to strengthen further its position in the centre of the CE knowledge network it has built. Working on industry imperatives and the perceived needs of the fashion industry and being underpinned by the $\mathrm{CE}$ approach to the development of products, services and experiences, results in new knowledge creation, with AMFI deeply embedded in a vital, evolving and informed knowledge network.

\section{Circular economy and deep learning:}

The CE's lens for looking at problems in an interconnected and interdisciplinary way is a useful template for deep learning (Biggs and Tang, 2007:27). Deep learning ensures students' progress from a strategic mode of learning, acquiring information to pass assessment, to a fundamentally self-directed and inspired attitude to learn, interpret and apply knowledge. Circularity offers a unifying framework for systems thinking: a holistic approach to identifying challenges, defining problems and exploring potential solutions that transcends traditional disciplinary boundaries. Because $\mathrm{CE}$ demands a reconfiguration in how we produce products, so does it demand new ways of defining curricula that facilitate interdisciplinary cooperative learning, with knowledge sharing at its core. It requires methods of investigation and reconstruction that facilitate the examination, interpretation and reconfiguring of seemingly disparate topics. Warburton (2003) suggests that deep learning is particularly important to complex topics such as the CE because it involves paying attention to underlying meanings, recognizing causal relationships, cross-referencing research and imaginative reconstruction of previously unconnected issues. The multiple themes of the CE require internalization by students, necessitating independent thinking and multi-perspective reflective judgement (King \& Kitchener, 2004:48) that enable learners to define personal meanings and prioritize concepts that can be embedded within their practice. CE presents a dynamic learning environment where underpinning knowledge and research is evolving and accumulating rapidly. It lacks the accepted structures, boundaries and seminal theories that underpin more long-established areas of study, linked with more rigid patterns of teaching and learning. Critically, this means the pedagogical process for CE learning must be problembased, focusing on an effective combination of mastery and discovery learning. Mastery learning is where students are encouraged to take responsibility for their learning but the teacher retains control over the syllabus, guiding learning though providing essential content and planned sequences that demonstrate connections, or supports step-by-step understanding of a problem. Discovery learning focuses on developing personal meanings though exploring 
topics based on curiosity, independently, in an open environment (Carroll, 1963; Bruner, 1960; Rogers 1969; cited in Warburton 2003:48).

This creates a pedagogical challenge: on the one hand, CE's framework can provide the scaffolding students need to take a strong personal interest in its issues, driving their intrinsic motivation to learn more deeply about associated topics, to actively contribute to interdisciplinary discourse and to discover real solutions for the creation of a sustainable future for the fashion industry; but on the other hand, the environment must be conducive to learning i.e.:

- providing a visible conceptual framework with which to navigate CE's complexity, equipping students with meta-learning skills prior to taking a 'deep-dive' approach to $\mathrm{CE}$ that enables them to explore, interpret and define meanings

- combining mastery and discovery learning to show that cooperative and interdisciplinary approaches work

- offering flexible forms of assessment that they can use to demonstrate their learning in a variety of ways

- avoiding excessive workloads where the focus is on delivery rather than giving time to interpret and develop personal relevance

- allowing time to investigate the complex interconnections of a CE.

These being absent, the opportunity for deep learning is restricted as students tend to adopt a surface learning approach when there is a motivational deficit, or anxiety caused by feeling out of their depth.

The stages of developing students' learning capabilities are illustrated in Figure 2. This broadly illustrates an agenda for building the meta-learning skills and contextual knowledge students require that equips them with ability to engage in deep learning activities. Taking a constructivist approach, each stage represents evolution in competencies and capabilities that enable critical, multi-perspective reflective judgement (King \& Kitchener, 2004:48).

\begin{tabular}{|c|c|c|c|c|}
\hline First Year & | & Second Year & $\mathbf{I}$ & The Reality School \\
\hline EQUIP & I & INSPIRE & I & ENGAGE \\
\hline FOCUS: & | & FOCUS: & I & FOCUS: \\
\hline Eco-literacy and sustainability & | & Cradle to Cradle, circular economy (CE) orientation & | & Embedding CE and change \\
\hline $\begin{array}{l}\text { CONTENT } \\
\text { Recognize need for change }\end{array}$ & | & $\begin{array}{l}\text { CONTENT } \\
\text { Embed CE in practice through curiosity and enhanced } \\
\text { personal meaning }\end{array}$ & & $\begin{array}{l}\text { CONTENT } \\
\text { Embody CE agenda } \\
\text { enabling change }\end{array}$ \\
\hline Develop critical awareness of key concepts & & Engage with independent thinking & 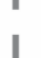 & Employ multi-perspective reflection \\
\hline $\begin{array}{l}\text { Investigate range of conceptual and } \\
\text { material content }\end{array}$ & I & $\begin{array}{l}\text { Demonstrate through cross-disciplinary projects: } \\
\text { industry and practitioner informed }\end{array}$ & I & $\begin{array}{l}\text { Realize through trans-disciplinary projects: } \\
\text { industry and practitioner led }\end{array}$ \\
\hline $\begin{array}{l}\text { Explore dynamic relationships, developing } \\
\text { structures and processes of evolving field }\end{array}$ & 1 & $\begin{array}{l}\text { Understand revelatory / Problem-based learning approach: } \\
\text { focus on analytical techniques and value judgment }\end{array}$ & I & $\begin{array}{l}\text { Apply imaginative reconstruction (development in } \\
\text { inter-connected solutions) through action research }\end{array}$ \\
\hline $\begin{array}{l}\text { Investigate interconnections } \\
\text { and interdependence }\end{array}$ & 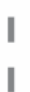 & $\begin{array}{l}\text { Understand life-cycle of products and broad range of } \\
\text { impacts and causal relationships }\end{array}$ & $\begin{array}{l}\text { I } \\
\text { I }\end{array}$ & $\begin{array}{l}\text { Design new circular economy systems, } \\
\text { concepts and design responses }\end{array}$ \\
\hline $\begin{array}{l}\text { Explore resource limitations and } \\
\text { environmental/ethical impacts }\end{array}$ & 1 & Evaluate environmental value of actions \& initiatives & | & Define new strategies \\
\hline TEACHING MODE: Mastery & " & TEACHING MODE: Blended: Mastery, Discovery & $\mathbf{I}$ & TEACHING MODE: Discovery \\
\hline
\end{tabular}

Figure 2. Model of Expected Student Learning Progression 
The level at which AMFI has integrated a CE agenda into the Reality School varies. This is because there are multiple subject areas contained within courses and programmes, each with its own complexities, and all at different points along the path to full integration of a CE agenda across the Reality School. Elements such as subject contexts, perceived relevance, student feedback, assessment structure, course design, review and planning exercises influence the different rates at which a CE agenda is being integrated. Hurnery, et al (2016) offers a useful model for considering the levels of integration of sustainability within a faculty or school. The article presents an adapted version of this model (Figure 3.) based on CE themes in AMFI's Reality School and its constituent programmes and relate it to pedagogic theory around CE's relationship with deep learning (Warburton, 2003:49). The model is used to evaluate the different levels of CE integration achieved in each of the case study examples at AMFI's Reality School.

\begin{tabular}{|c|c|c|c|c|c|c|}
\hline $\begin{array}{l}\text { Level of } \\
\text { Integration }\end{array}$ & Description & Examples & $\begin{array}{l}\text { Learning } \\
\text { Aim }\end{array}$ & $\begin{array}{l}\text { Learning } \\
\text { Style }\end{array}$ & Benefits & Challenges \\
\hline Additive & $\begin{array}{l}\text { CE 'bolted- } \\
\text { on' to course } \\
\text { content }\end{array}$ & $\begin{array}{l}\text { Changes topics } \\
\text { or units, } \\
\text { develop eco- } \\
\text { literacy. } \\
\text { Industry } \\
\text { reflective }\end{array}$ & $\begin{array}{l}\text { Orientatio } \\
\mathrm{n}, \\
\text { develops } \\
\text { awareness } \\
\text {. }\end{array}$ & $\begin{array}{l}\text { Mastery, } \\
\text { approach, } \\
\text { surface } \\
\text { learning }\end{array}$ & $\begin{array}{l}\text { Quickly } \\
\text { infuses } \\
\text { content, can } \\
\text { experiment } \\
\text { with content. }\end{array}$ & $\begin{array}{l}\text { Limits range } \\
\text { and depth of } \\
\text { content }\end{array}$ \\
\hline Integrative & $\begin{array}{l}\mathrm{CE} \\
\text { Integrated } \\
\text { within } \\
\text { unit/minor \& } \\
\text { updated } \\
\text { learning } \\
\text { outcomes }\end{array}$ & $\begin{array}{l}\text { Pedagogy, } \\
\text { learning } \\
\text { processes, } \\
\text { assignment } \\
\text { structure. } \\
\text { Develop CE } \\
\text { expertise, } \\
\text { industry } \\
\text { informed. }\end{array}$ & $\begin{array}{l}\text { Develops } \\
\text { perspectiv } \\
\text { es }\end{array}$ & $\begin{array}{l}\text { Mastery and } \\
\text { Discovery, } \\
\text { comprehensi } \\
\text { on driven. }\end{array}$ & $\begin{array}{l}\text { Shifts focus } \\
\text { and overall } \\
\text { learning } \\
\text { objectives } \\
\text { allows more } \\
\text { holistic } \\
\text { subject } \\
\text { viewpoints. }\end{array}$ & $\begin{array}{l}\text { Enabling } \\
\text { students } \\
\text { meta- } \\
\text { learning } \\
\text { skills prior } \\
\text { to } \\
\text { engagement } \\
\text { s in topics. }\end{array}$ \\
\hline $\begin{array}{l}\text { Transformat } \\
\text { ive }\end{array}$ & $\begin{array}{l}\text { CE Thematic } \\
\text { of entire } \\
\text { course. }\end{array}$ & $\begin{array}{l}\text { Changes } \\
\text { curricula, } \\
\text { assessment } \\
\text { structure, drives } \\
\text { teaching and } \\
\text { research focus. } \\
\text { Industry linked }\end{array}$ & $\begin{array}{l}\text { Independe } \\
\text { nt } \\
\text { Thinking }\end{array}$ & $\begin{array}{l}\text { Problem- } \\
\text { based } \\
\text { learning, } \\
\text { focused } \\
\text { intrinsic } \\
\text { motivation to } \\
\text { learn, } \\
\text { personal and } \\
\text { project goals }\end{array}$ & $\begin{array}{l}\text { Facilitates a } \\
\text { cross- } \\
\text { disciplinary } \\
\text { learning } \\
\text { environment } \\
\text { for deep } \\
\text { learning. }\end{array}$ & $\begin{array}{l}\text { Challenges } \\
\text { expertise of } \\
\text { existing } \\
\text { staff, } \\
\text { requires } \\
\text { course re- } \\
\text { design and } \\
\text { alignment of } \\
\text { school-wide } \\
\text { learning } \\
\text { goals. }\end{array}$ \\
\hline Engaged & $\begin{array}{l}\text { CE } \\
\text { underpins } \\
\text { school-wide } \\
\text { pedagogic } \\
\text { practice } \\
\text { and research } \\
\text { and }\end{array}$ & $\begin{array}{l}\text { Informed by } \\
\text { knowledge } \\
\text { partnerships }\end{array}$ & $\begin{array}{l}\text { Imaginati } \\
\text { ve } \\
\text { reconstruc } \\
\text { tion }\end{array}$ & $\begin{array}{l}\text { Experiential } \\
\text { motivation, } \\
\text { Practice } \\
\text { embedded, } \\
\text { value } \\
\text { judgements, } \\
\text { employability }\end{array}$ & $\begin{array}{l}\text { Action } \\
\text { research } \\
\text { framework, } \\
\text { Curricula } \\
\text { industry-led, } \\
\text { research and } \\
\text { professional } \\
\text { practice }\end{array}$ & $\begin{array}{l}\text { Requires } \\
\text { cultivation } \\
\text { and } \\
\text { developmen } \\
\text { t of } \\
\text { knowledge } \\
\text { partnerships }\end{array}$ \\
\hline
\end{tabular}


knowledge

exchange. goals. Life- synergies for

long learning. teaching.

Figure 3. Levels of Circular Economy integration into curricular

\section{Case study - review of project types and impact}

The learning environment of the Reality School acts as an experimental space where students take on the challenges of $\mathrm{CE}$ and participate in the resulting projects, taking on key research, developmental and leadership roles and responsibilities that drive their own learning. The four case studies conducted in AMFI's Reality School demonstrate different levels of integration of a CE agenda and embeddedness into curricula in practical terms, it highlights the learning environments and assessment methods of the Reality School. The level of integration of CE achieved was established through analysis of the course documentation and through interviews with respondents 1 to 5 and are defined in Figure 3.

\section{D Hypercraft (Programme / Minor)}

The 3D Hypercraft programme is a minor offered to both Fashion and Management and Fashion and Design students. They explore concepts of Cradle to Cradle design from a technical research and garment construction perspective, by using technologies focused on design for environment and life cycle extension criteria. The emphasis is on discovery learning; students research and implement concepts in an experimental environment that is supervised by a team with expertise in technical fabric research, digital pattern cutting, virtual prototyping, body-scanning technology and CAD software. Students are required to create an avatar, design three completed digital outfits, including blocks, to test and consider textiles and to create $3 \mathrm{D}$ visualizations that include animations. Reflective tools include a digital process book presented as a blog. This is presented and evaluated at an industry attended exhibition.

During interviews with staff it was clear that 3D Hypercraft demonstrates a transformative level of CE engagement. It was possible to pin-point a shift in the attitude towards circularity in this area of the curriculum.

We are feeling the necessity of a change for some time [...]. Last year we sat down and said this level isn't enough anymore we need to do it on all levels it has become a necessity throughout the complete learning line.

(Respondent 4).

3D Hypercraft is a technology-driven, future-focused programme, utilizing 3D environments and virtual prototyping tools to explore core themes of zero-waste, durable design, ecomaterials selection and 'seasonless' style. The teaching and learning, assessment, research activities and themes within the course are encapsulated in the unit assignment brief 'Global Change Collection' that evidently challenges both students and staff, apparent from comments made during the interview 'but of course, with this comes the responsibility of having the knowledge, skills, the whole package' (Respondent 4).

Staff acknowledged, and have embraced, the need for them to provide students with the knowledge and direction to take on these challenges. As a result, the students realize a collection of high-end outfits whilst acting as developers of innovation in sustainable 
solutions for the industry. Given the subject matter, and likely outcomes of the programme, achieving this level of engagement from the students (and staff) is expected, but should not be assumed. Considerable investments in technology (software and machinery), staff development and external engagement have all acted as drivers for the level of integration achieved.

\section{iNDiViDUALS (Programme / Minor)}

iNDiViDUALS is a premium Dutch womenswear brand initiated by AMFI in 2006 and it is centred on the demands of the fashion industry. Design, management and branding students work collaboratively to design, develop and commercialize new collections, with two intakes of thirty students per year, that correspond with autumn/winter and spring/summer seasonal deadlines. Typical of the fashion industry, the production of the garments is outsourced to China. The teams control iNDiViDUALS, taking on specifically-defined job roles based on product management, brand development and design activities and course leaders act as coaches, supporting students' activities. iNDiViDUALS holds catwalk shows associated with each new collection, with clothing sold in the AMFI statement store.

iNDiViDUALS is assessed as achieving an additive approach to integrating the CE agenda. Fundamentally, it reflects how the fashion industry is currently organized. Its focus on traditional seasons, time-to-market, outsourcing and luxury brand marketing is evidently both successful and valuable experiential learning. Transitioning to a CE framework in this context represents many of the same challenges the fashion industry itself faces. This represents a notable opportunity as a space for the challenges of the CE in the context of fashion's commercial drivers to be explored, but to integrate a CE agenda fully into the curricula for iNDiViDUALS requires redesigning the programme of learning entirely. It cannot be partially undertaken, but must be at the core of the programme if it is to be successfully adopted, which staff recognise as necessity 'My vision is that sustainability is not a topic it is the starting point for everyone. If it's not sustainable it's not gonna happen' (Respondent 3). AMFI has indeed temporarily suspended the programme while these challenges are considered and the suspension of the iNDiViDUALS programme demonstrates the extent to which external influences can affect the different rates at which $\mathrm{CE}$ frameworks can be embedded into different programmes of study, an important change management consideration.

A notable issue with CE integration into the Reality School is that, compared to fashion design and fashion management activities (that require fundamental shifts in their underpinning theory and practice toward CE), fashion branding could be perceived as relatively simple. It requires a switching of aims, reorienting the persuasive communications used to influence consumer's over-consumption, price sensitivity or status concerns into responsible brand narratives, focused on transparency, eco-literacy and slow fashion. Promoting behaviour changes such as 'borrowing' and returning garments into take-back schemes and purchasing eco-fashion for realistic prices from brands with ethical and environmental responsibility is a critical and necessary step change in how the fashion industry markets its products. The CE must be perceived by consumers as the new social norm for both consumers and fashion firms.

\section{MA Fashion Enterprise Creation (Course)}


Focusing on Fashion Entrepreneurship, this course integrates the CE agenda at an engaged level and is embedded in the teaching, learning and research agenda students must undertake for their work in establishing a new fashion enterprise, culminating in a completed business plan that includes the business opportunity, investment readiness and sourcing strategy of their enterprise. It specifically engages students in developing a sustainable vision that underpins the entire business concept, grounded in teaching and research discourse around the CE and students' ability to evaluate effectively social and environmental impacts using issue mapping techniques and risk cartography, synthesized through developing suitable research frameworks. The course is partnered with a number of CE focused enterprises including Circle Economy, Made-By and Fashion for Good (FFG), an innovation hub and start-up accelerator focused on delivering sustainable fashion offers business incubation space to new enterprises on the course based on the quality of students' business proposals. The course also integrates teaching from industry practitioners linked to these organizations and position students at the centre of a knowledge network that accelerates their learning and supports their sustainable business ambitions.

\section{Beyond Green (Network Event)}

Although Beyond Green is an event rather that a programme at AMFI it is a key part of how $\mathrm{CE}$ is being embedded into AMFI's Reality School and represents an engaged level of CE integration. This annual symposium on the future of fashion is joint-organized by Circle Economy and AMFI that uses the collective power of students, industry players and AMFI academics to tackle critical issues in the fashion system and CE focused solutions. It is an aspirational and educational event that envisions a sustainable fashion industry. The first part of the event is inspirational, a series of keynote speakers leading the CE movement. The second part, relevant to CE integration into the Reality School, involves collaborative workshops themed on specific CE challenges. Industry partners bring their real-life challenges to the table and work with students to develop potential sustainable initiatives. This not only cements AMFI's position within the knowledge network that is informing its transition toward a CE integrated curricula, but brings in new potential partners, projects and opportunities that can be integrated into the Reality School concept.

Evidence of this is the 'Hello-Goodbye' initiative, a student-led collective launched by students with a passion for sustainability and a vision for a circular fashion industry. Their manifesto includes curriculum recommendations for AMFI showing that they have generated as a future vision for fashion education. This illustrates students' engagement in the concepts of CE, its level of embeddedness at AMFI and the positive effects of students' intrinsic motivation within a deep learning framework. To be driven by their intent to learn so positively that they would like to be an active part in developing future learning is high praise indeed.

\section{Findings}

Systematic review and comparison of the case studies against the 3 models (Figure 1. 2. and 3.) highlights the key areas successfully addressed by AMFI, in its adoption of a CE agenda of education.

- Flexibility: the Reality School represents a model that can absorb changes in the knowledge economy and respond to them accordingly. The School's autonomy and control over curriculum content and its ability to change it easily allows it to be responsive to industry requirements and new projects that benefit the students with contemporary and engaging teaching and learning. 
- Space to challenge subject context and norms: the Reality School is so named as it links directly with industry-led \& employability frameworks. Such frameworks can directly conflict with the CE agenda and thus, learning outcomes can too. The iNDiViDUALS case study illustrates this clearly. Its fundamental design is based on simulating current fashion industry practices in design, sourcing, merchandising, marketing, and branding. The priority is commercialisation; its learning outcomes are reflective of this. It represents the system which CE seeks to re-engineer with a differing set of considerations and values. It is important to recognize that, dependent on the level on conflicting priorities, change in different programmes will happen at different rates. Some programmes, particularly those that are contextual or more experimental, such as 3D Hypercraft, may be more conducive to CE adoption or adaptation. Those that closely simulate current practices may require a more careful balance of current employability and commercial standards combined with innovative new CE curricula. The student's ability to recognize conflicts, take a critical view on differing perspectives and understand their position as change agents, becomes key and makes deep learning essential. In the Reality School, transition toward this concept is illustrated by the Hello-Goodbye initiative.

- Embedded operational learning skills: the meta-learning skills that enable the students to study at the Reality School level need to be in place before students focus on CE challenge. Because a CE agenda is as yet not fully embedded across all years, some of the programmes such as iNDiViDUALS, need to receive students with a greater level of prior learning before they can incorporate $\mathrm{CE}$ developments into the curricula.

- Challenges that link to real industry opportunities to demonstrate the CE in practice: there is a marked transition from an 'additive/integrative' stage to a transformative/engaged stage, because this transition involves a stronger and planned connection between courses, programmes and curricula that links students' CE learning across their entire student experience. If the 'inspire and learn' years are defined as preparatory, there needs to be obvious linkages that form a visible conceptual model of learning progression, culminating in outcomes that realise the CE agenda.

- A CE knowledge network: it is critical to have external engagement like the Beyond Green event and building a CE network prior to introducing CE education. It is easier for staff to declare commitment to circularity when its concepts and ideas are already present. For example, partnership with CE prior to an institutional declaration of commitment to CE education allows staff time for professional development and acquisition of knowledge alongside students beginning to direct their learning towards the agenda. This incremental approach supported by partnerships with industry professionals and specialists facilitates and empowers all stakeholders in the transition process.

\section{Conclusion and Recommendations}

In summary, the article presents a framework for a CE agenda for fashion education through a Reality School concept that could be adopted by other specialist fashion education institutions. The 3 models articulate specific aspects of the framework:

- Figure 1. The Reality School Structure. An approximation of the reality school and how it functions, this model provides an organizational overview.

- Figure 2. Model of Expected Student Learning Progression which demonstrates desired levels of learning and skills of students across three years of study. A workable model of student progression that will enable fashion institutions to map out 
the curriculum content and levels of understanding that need to be achieved by students in the journey towards the adoption of CE in their own education.

- Figure 3. Levels of CE integration into curricular. A model of embeddedness identifying the different levels and challenges of embedding $\mathrm{CE}$ into a fashion education institution (adapted from Hurnery, et al (2016)) to be used as an evaluative tool allowing institutions to assess their own levels of $\mathrm{CE}$ integration.

It also proposes that integrating the $\mathrm{CE}$ agenda into fashion education institutions requires the following structures;

- Flexible school models that can absorb changes in the knowledge economy and respond to them accordingly; a fashion school's autonomy and control over curriculum content and their ability to change it easily allows for them to be responsive to industry requirements and new projects that benefit the students with contemporary and engaging teaching and learning. Without flexibility in its principle architecture, integration of a $\mathrm{CE}$ agenda into the curricula would be problematic.

- Space to challenge contextual norms: an emphasis on experiential learning and employability frameworks that reflect industry norms can create conflict with the CE agenda. Learning outcomes of programmes that mirror current fashion industry practice may find CE transition paradoxical. What is important is the students' and academics ability to recognize these conflicts, take a critical view of them and understand their position as change agents.

- Partnerships with knowledge providers who can offer support in the implementation of CE curricular; it cannot be assumed that institutions are able to provide the required knowledge for $\mathrm{CE}$ curricula development and integration.

- Research and knowledge exchange strategies: facilities for professional development are required for teaching staff to develop their knowledge around CE. It cannot be assumed that, without this support, staff will be able to design, embed and deliver innovative CE pedagogy.

It is imperative that a CE agenda of education is adopted in fashion schools, thereby ensuring that the next generation of fashion professionals is able to bring about a sustainable fashion industry in a progressive, innovative and effective deep learning environment. While ensuring the proposed structures are in place does not guarantee the successful integration of the $\mathrm{CE}$ agenda into curricula, it does provide an opportunity for institutions to identify how they might begin or further continue a change in educational direction towards a $\mathrm{CE}$ agenda. As is evident from the case studies, the change will be incremental and will take time. The change cannot be top down, it must be embraced by staff and students alike with opportunities for growth at all levels, and supported by the institutional structures, ensuring that all stakeholders are included in the transformation.

\section{References}

Andrews, D. (2015). The circular economy, design thinking and education for sustainability. Local Economy, 30(3), pp.305-315.

Better Cotton Initiative. (2017). Home - Better Cotton Initiative. [online] Available at: http://bettercotton.org [Accessed 5 Nov. 2017].

Biggs, J. and Tang, C. (2007). Teaching for quality learning at university. 3rd ed. Milton Keynes: Open University Press. 
Blacksmithinstitute.org. (2012). Blacksmith Institute: World's Worst Pollution Problems Report. [online] Available at: http://www.blacksmithinstitute.org/press-release-2012world-s-worst-pollution-problems-report.html [Accessed 5 Oct. 2017].

Business of Fashion Website (2017), 'Global Fashion School Rankings 2017. Amsterdam Fashion Institute', https://www.businessoffashion.com/education/rankings/2017/schools/amsterdamfashion-institute?type=bachelors. Accessed 29 ${ }^{\text {th }}$ October 2017.

Conca, J. (2015). Making Climate Change Fashionable - The Garment Industry Takes on Global Warming. [online] Forbes.com. Available at: https://www.forbes.com/sites/jamesconca/2015/12/03/making-climate-changefashionable-the-garment-industry-takes-on-global-warming/\#478930d979e4 [Accessed 12 Oct. 2017].

Ellen Macarthur Foundation (2016). Delivering the Circular Economy: A Toolkit for Policy Makers. [online] Cowes, Isle of Wight: Ellen Macarthur Foundation. Available at: https://www.ellenmacarthurfoundation.org/assets/downloads/publications/EllenMacArthu rFoundation_PolicymakerToolkit.pdf [Accessed 20 Jul. 2016].

GCUfairfashioncenter.org. (2017). The GCU Fair Fashion Center - Proving the Business Case for Sustainability. [online] Available at: https://www.gcufairfashioncenter.org/index [Accessed 8 Oct. 2017].

Ghisellini, P., Cialani, C. and Ulgiati, S. (2016). A review on circular economy: the expected transition to a balanced interplay of environmental and economic systems. Journal of Cleaner Production, 114, pp.11-32.

Greenpeace (2016). Toxic Threads: The Big Fashion Stitch Up. Amsterdam: Greenpeace.

Hasan, K. and Miah, M. (2014). Impacts of Textile Dyeing Industries Effluents on Surface Water Quality: A Study on Araihazar Thana in Narayanganj District of Bangladesh. Journal of Environment and Human, 2014(3), pp.8-22.

Hiller Connell, K. and Kozar, J. (2012). Sustainability knowledge and behaviors of apparel and textile undergraduates. International Journal of Sustainability in Higher Education, 13(4), pp.394-407.

Hurney, C., Nash, C., Hartman, C. and Brantmeier, E. (2016). Incorporating sustainability content and pedagogy through faculty development. International Journal of Sustainability in Higher Education, 17(5), pp.582-600.

Junyent, M. and de Ciurana, A. (2008). Education for sustainability in university studies: a model for reorienting the curriculum. British Educational Research Journal, 34(6), pp.763-782.

King, P. and Kitchener, K. (2004). Reflective Judgment: Theory and Research on the Development of Epistemic Assumptions Through Adulthood. Educational Psychologist, 39(1), pp.5-18.

Leerberg, M., Riisberg, V. and Boutrup, J. (2010). Design responsibility and sustainable design as reflective practice: an educational challenge. Sustainable Development, 18(5), pp.306-317. 
Maher, S. (2010). Taking Liberties: The Story Behind the High Street. [online] War on Want. Available at: http://www.waronwant.org/resources/taking-liberties [Accessed 10 Oct. 2017].

McDonough, W. and Braungart, M. (2002). Cradle to cradle. New York: North Point Press.

O ECOTEXTILES. (2011). Estimating the carbon footprint of a fabric. [online] Available at: https://oecotextiles.wordpress.com/2011/01/19/estimating-the-carbon-footprint-of-afabric/ [Accessed 5 Oct. 2017].

Warburton, K. (2003). Deep learning and education for sustainability. International Journal of Sustainability in Higher Education, 4(1), pp.44-56. 